\title{
The Influence of Motivation, Organizational Culture And Performance of Teacher Professional At MTs Tayu- Pati
}

\author{
Fajriana Nur Asmawati ${ }^{1}$, Sukirman ${ }^{2}$, Moh. Khanzunuddin ${ }^{3}$ \\ \{rie.irham@gmail.com ${ }^{1}$ \} \\ ${ }^{1}$ Basic Education Study Program, Faculty of Teacher Training and Education, Universitas Muria Kudus, \\ Indonesia \\ ${ }^{2}$ Management Study Program, Universitas Muria Kudus, Indonesia \\ ${ }^{3}$ Indonesian Language and Literature Education Study Program Universitas Muria Kudus, Indonesia
}

\begin{abstract}
Abstarct. This study aims to analyze the influence of motivation and organizational culture and teacher performance at all of MTs in Tayu. This research was conducted at MTs Tayu with sample of 136 teachers using proportional random sampling technique that is taking samples proportionally. Data analysis tool used in this research is multiple linier regression model. The instruments used are quesionnaies tested with validity and realibility testing. The results of the study showed that the motivation significantly and positively influenced teacher profesional in MTs Tayu. Organizational culture significantly and positively influenced teacher profesional in MTs Tayu. Performence significantly and positively influenced teacher profesional in MTs Tayu. The motivation, organizational culture and performence together significantly and positively influenced teacher profesional in MTs Tayu.
\end{abstract}

Keywords: Motivation, Organizational Culture, Performance, Teacher Profesional

\section{Introduction}

\subsection{Background of Study}

Improving the quality of education is determined by the readiness of human resources involved in the education process. Teachers are one of the determinants of the high and low quality of educational outcomes having a strategic position, so every effort to improve the quality of education needs to pay great attention to improving teachers in terms of both quantity and quality.

The teacher is an important and valuable asset for the school because if it is managed well then the teacher's performance will be good, this is due to several factors including motivation and organizational culture this factor is related to job satisfaction and performance is what you want to aim for that will affect the image or impression of a educational organization itself.

Latif, et al (2017) revealed that the performance of a teacher in carrying out their duties will be optimal if the teacher has the ability to carry out their duties as a teacher. This is emphasized by Gomes in Latif, et al (2017) that the factors that influence the achievement of 
competent teachers must be based on optimal competency mastery, because the level of mastery of teacher competence is very influential on the level of teacher performance (latif, et al., 2017).

Based on observations made by the author in July 2019 in several MTs in Tayu-Pati shows that most teachers who teach in MTs still do not reflect high motivation. This can be seen from the following phenomena: there are still teachers who do not prepare a complete set of learning tools that are in accordance with the situation and condition of the school, there are still professional teachers who are less eager to pay attention to their students as well as in bringing their students to an atmosphere of learning that is innovative and fun and there are still teachers who lack discipline in implementing learning.

In addition to motivation, a conducive school organization culture is a prerequisite for effective teaching and learning. The culture of a school organization is a characteristic of a school that can be identified through its values, the attitudes it has, the habits that it displays, and the actions exhibited by all school personnel that form a special unity of the school system.

In the field, there are still a number of schools that have not been able to create a conducive organizational culture. This can be demonstrated by the lack of good relations between the principal and teachers, teachers and teachers, teachers and staff, and teachers and the community around the school. The culture of school organizations must be able to provide a situation that is able to build togetherness and unite the perspectives of teachers, staff and school principals in order to achieve goals, among others through the formation of mental work discipline with high dedication and loyalty to their work, the establishment of a strict vision and mission, guidance, good coordination of direction, and supervision for that required the principal who is able to manage all resources to improve the quality of education, involve components of the community, realize the culture of the school organization which is conducive to improving teacher performance.

The low performance of teachers in MTs based on interviews with the majority of teachers who teach in MTs can also be seen from the level of attendance and delays in school teachers. This can be caused by teachers having to teach in more than one school to make up for the lack of teaching hours and the low salaries earned by these teachers. The low performance of teachers can be seen from the planning and preparation in teaching, student evaluation and service to students. The teacher makes teaching administration completeness only as a condition for teacher accreditation and inpassing. This is due to the low supervision of school principals, principals do not carry out monitoring and evaluation of teacher performance seriously.

Mishan (2014) explained that the results of data analysis showed that teacher work motivation and organizational culture together had a positive and significant effect on performance. It was concluded that teacher work motivation and organizational culture are factors that can influence teacher performance, but organizational culture is the most prominent factor in influencing teacher performance. Teacher performance can be said to be good if the learning device has been arranged well and produces good learning outcomes.

The development of teacher professionalism is a means for the successful implementation of the 2013 curriculum to date. Therefore, teachers must have certain personal quality standards, which include responsibility, authority, independence, and discipline. The teacher is the main actor of learning activities that interact directly with students in the learning process activities. The success or failure of efforts to improve the quality of education is largely determined by the ability of the teacher to carry out the main task as a manager of classroom 
learning activities. The importance of the teacher's role requires the teacher to have competencies that are in accordance with the demands of the profession.

Agus F. Tamyong in Usman (2010: 15) states that the understanding of a Professional teacher is a person who has special abilities and expertise in the field of teacher training so that he is able to carry out his duties and functions as a teacher with maximum abilities. Teacher education qualifications are in accordance with the minimum prerequisites determined by the requirements of a professional teacher. work or activities carried out by a person and a source of living income that requires expertise, skills or skills that meet certain quality standards or norms and require professional education (article 1 paragraph 4 of law Number 14 of 2005).

Furthermore, in exercising professionalism authority, teachers are required to have a diverse set of abilities (competency). In the Law of Teachers and Lecturers number 14 of 2005 and government regulation number 19 of 2005 stated that teacher competencies include personality competencies, pedagogical competencies, professional competencies and social competencies. The enactment of these laws and regulations requires teachers to improve their professionalism through training, writing scientific papers, and so on.

Based on the description that has been described above, the goal to be achieved from this study is to find empirical evidence about: (a). The influence of motivation on teacher performance in MTs. (b). The influence of organizational culture on teacher performance in MTs. (c). The effect of teacher performance on teacher professionalism in MTs. (d). The influence of motivation on teacher professionalism in MTs. (e). The influence of organizational culture on teacher professionalism in MTs.

\subsection{The Purpose of the Study}

This Research is done to analyse and get empiris description about:

a. The effect of motivation on teacher performance in MTs in Tayu?

b. The influence of organizational culture on teacher performance in MTs in Tayu?

c. The effect of performance on teacher professionalism in MTs in Tayu?

d. The effect of motivation on teacher professionalism in MTs in Tayu?

e. The influence of organizational culture on teacher professionalism in MTs in Tayu?

\subsection{Review of Related Literature}

\section{Motivation}

Motivation is the giving of a driving force that creates the excitement of one's work, so that they will cooperate, work effectively and be integrated with all their efforts to achieve satisfaction (Hasibuan 2014: 95). "Motivation is a process that explains the strength, direction, and perseverance of someone in an effort to achieve goals" (Robbins and Judge, 2015: 129). "Motivation is a set of forces that cause people to engage in behavior in a certain way" (Moorhead and Griffin 2013: 36). Another definition according to Cascio in Hasibuan (2014: 95) motivation is a force that results from one's desire to satisfy his needs. According to Uno (2014: 71) teacher work motivation is nothing but a process undertaken to move teachers so that their behavior can be directed to concrete efforts to achieve the stated goals.

"Motivation that predispotion (itself the subject of mush control) within the individual which arouses sustained and direct his behavior. Motivation involves such factors as biological and emotional needs that can only be inferred from observation behavior. " 
According to some of the definitions explained above it can be concluded that what is meant by work motivation is something that can cause enthusiasm or drive to work individually or in groups towards work to achieve goals. Teacher work motivation is a condition that makes the teacher have the will or need to achieve certain goals through the implementation of a task.

\section{Organizational Culture}

The demand for organizational culture to appear to carry out innovative and creative activities as mentioned by Robbins above is not yet a culture among teachers. As an example is what Mustofa stated in Radar Lampung daily, according to him there are still many teachers who are not accustomed to doing creative learning, but tend to manage classes conventionally as they were taught by their teachers (Radar Lampung, Thursday-22 November 2012).

Organizational culture is the belief and enthusiasm of an organization that is expressed, for example in the values and norms that are generally guided by how people should act with one another, the cooperative relationships that should be developed and attitudes to make changes. These norms are assumptions that are deeply believed that cannot be expressed and known, except by the way they are understood.

It can be concluded that work culture or organizational culture is a form of behavior that is displayed by a society or organization as a manifestation or mirror of the values and norms that are believed and used as guidelines, and expectations that want to be achieved. The direct reflection can be in the form of the attitude and actions of the leaders and subordinates, how they choose how to deal with problems, and how they think and behave, including how they work together.

\section{Teacher Performance}

Patricia King in Uno and Lamatenggo (2014: 64) states that performance is a person's activity in carrying out the main tasks assigned to him. Meanwhile according to Mulyasa (2013: 75) teacher performance is the teacher's activity in managing student learning which includes understanding of students, designing and implementing learning, evaluating learning outcomes and developing students to actualize their various potentials.

While Supardi (2014: 54) stated that teacher performance is the ability of a teacher in carrying out learning tasks in madrasas / schools and is responsible for students under his guidance by increasing the learning achievements of students. Teacher performance is the ability and success of teachers in carrying out learning tasks (Supardi, 2014: 23) Teacher performance is the work of teachers reflected in how to plan, implement and assess teaching and learning processes whose intensity is based on work ethic, and professional discipline in the process learning (Uno, 2014: 86).

From this discussion it can be concluded that teacher performance is an activity carried out in the context of membingbing, educating, and transferring knowledge to students according to their professional abilities and the results or levels of success achieved by a teacher in their field of work according to certain criteria and evaluated by the leadership of educational institutions especially principals.

\section{Teacher Professionalism}


According to Kunandar (2011: 45), professionalism comes from the word profession. In the large dictionary of Modern Indonesian, the profession is defined as work based on expertise, which is derived from the word profector which means, announcing, expressing confidence, affirming opening, acknowledging, and justifying.

According to Payong (2011: 6), a profession is a position or occupation that demands expertise from its members. The expertise was obtained through higher education which was taken in a short time with a strong scientific foundation and a high level of difficulty. A profession cannot be done by people who only have primary or secondary education but by people who have higher education who are accustomed to high-level thinking and thinking. A profession has complex concepts and theories so it takes a long time to study more deeply. According to Suyanto (2012: 26), professionalism is very important because professionalism will give birth to the best attitude for a teacher in serving the educational needs of students, so that later this attitude will not only benefit students, but also provide benefits for parents, the community and the school institution itself.

According to Kunandar (2011: 48), teacher professionalism has an important meaning as follows: (1) Professionalism guarantees the protection of the welfare of the general public. (2) Teacher professionalism is a way to improve the education profession that has been considered by some low society. (3) Professionalism provides the possibility of improvement and self-development that allows teachers to provide the best possible service and maximize their competence.

Teachers who have the main task is to print human resources in accordance with their maximum potential, are demanded to have high professionalism in their field. Mastering various matters related to the field under their control, in accordance with the education they are in charge of so that it is in line between the field of expertise with the professions they lead.

A professional educator has ten competencies, namely: (1) mastering the foundation of education, (2) mastering subject matter, (3) ability to manage teaching and learning programs, (4) ability to manage classrooms, (5) ability to manage learning interactions, (6) ) assess student learning outcomes, (7 ability to recognize and translate the curriculum, (8) recognize the functions and programs of guidance and counseling, (9) understand the principles and results of teaching, and (10) know and organize educational administration. These competencies are seen as pillar or the performance of a profession, this implies that a competent professional must be able to show the main character.

\section{Research Methods}

This research design uses quantitative descriptive research methods. In this study, the extent of the influence of organizational culture and job satisfaction of teachers on the performance of MTs school teachers in Tayu-Pati will be examined. The Population are: Teachers in MTs Al Huda Tayu MTs totaling 28 teachers. There are 40 teachers at MTs Miftahul Huda Tayu MTs. There are 13 teachers at MTs Nurul Huda. There are 15 Teachers at MTs Miftahul Falah. There are 40 teachers at Roudhotut Tholibin. The sample used was all teachers in the MTs Tayu with a total of 136 teachers. Sampling in each MTs will be carried out using proportional sample random sampling technique.

The Research Instruments is the main instrument of this study was a questionnaire. The preparation of the questionnaire begins by setting the operational definition of the variable which is then broken down into indicators that want to be measured. Data Analysis is a study requires data analysis and interpretation that aims to answer the questions of researchers in 
order to uncover certain social phenomena. Data analysis in this study uses the Structural Equation Modeling (SEM) program.

\section{The Result and Discussion}

\subsection{Effect of Motivation and Organizational Culture on Teacher Performance}

Increased motivation and organizational culture in MTs Tayu can have an impact on improving teacher performance, as the results of research indicate that teaching motivation has a positive and significant effect on teacher performance in MTs Tayu. That is, there is a direct effect between motivation and organizational culture of teaching with teacher performance, where when teaching motivation increases, teacher performance will also increase and vice versa when teaching motivation decreases, teacher performance will also decrease.

To measure teaching motivation using indicators, namely: Job Challenges, Responsibilities, Awards and Job Performance, Relationships with organizations, and Cooperation. Based on respondents' perceptions of the teaching motivation variable (X1) in filling out the questionnaire against 77 teachers with five statement items, the lowest mean score was obtained, namely the second statement item or X1.2 indicator of 4.13. This gives the meaning that some teachers consider that not all teachers are able to take responsibility with what is taught to students as perceptions of respondents who answered strongly disagree by $5.2 \%$, less agree by $3.9 \%$, agree by $58.4 \%$, and strongly agree with $32.5 \%$ of the statements that "I am able to take responsibility for what I teach students".

The highest mean score is the fifth statement item or X1.5 indicator of 4.35. This gives the meaning that the large teacher considers that the teachers at Soppeng 4 State Vocational School are able to work well together as the perception of respondents who answered strongly disagrees was only $2.6 \%$, disagreed at $1.3 \%$, less agreed at $5.2 \%$, agree with $40.3 \%$, and strongly agree with $50.6 \%$ of the statement that "I am able to work well with colleagues".

\subsection{Effect of Performance on Teacher Professionalism}

Increasing teacher professional competence in MTs Tayu can have an impact on improving teacher performance, as the results of research indicate that teacher professional competence has a positive and significant effect on teacher performance in MTs Tayu. That is, there is a direct effect between professional competence and teacher performance, where when professional competence increases, teacher performance will also increase and vice versa when professional competence decreases, teacher performance will also decrease.

To measure professional competence using indicators, namely: Able to master the substance of learning, Able to organize learning material, Able to adjust subject matter to the needs of students, Able to follow developments in Science and Technology, and Able to develop relevant learning methods and resources. Based on respondents' perceptions of the variable professional competence (X2) in filling out the questionnaire against 77 teachers with five statement items, the lowest mean score was obtained, namely the fourth statement item or X2.4 indicator of 4.09. This gives meaning that some teachers consider that the teacher has not been able to effectively follow the development of science and technology (science and technology) as well, as the perception of respondents who answered strongly disagree by $1.3 \%$, disagree by $3.9 \%$, less agree at $6.5 \%$, agreeing at $61.0 \%$, and strongly agreeing at $27.3 \%$ of the statement that "I am able to take responsibility for what I teach students".

The highest mean score is the fifth statement item or indicator X2.5 of 4.36. This gives meaning that the large teachers consider that the teachers at MTs Tayu are able to develop 
methods and learning resources for students in schools well, as the perception of respondents who answered strongly disagreed was only $2.6 \%$, disagreed at $1.3 \%$, agreeing to $49.3 \%$, and strongly agreeing to $46.8 \%$ of the statement that "I am able to work well with colleagues".

\subsection{Effects of Motivation, Organizational Culture and Performance on Teacher Professionalism}

Motivation, professional competence, and teacher education level in MTs Tayu can have an impact on improving teacher performance, as the results of research indicate that teaching motivation, organizational culture and teacher professional competence simultaneously have a positive and significant effect on teacher performance at MTs Tayu. That is, there is a direct influence between teaching motivation, organizational culture and performance on teacher professionalism and teacher performance, where when motivation to teach, organizational culture on teacher professionalism, the higher simultaneously, the teacher's performance will also increase and vice versa when teaching motivation, culture organizational and professional competencies are getting lower simultaneously, so teacher performance will also decrease.

Based on the observations of researchers in the MTs Tayu there are symptoms of low teacher performance marked by phenomena in the field, are: (1) the presence of teachers who are less engaged in the tasks that have been given, such as rarely entering and leaving assignments without permission; (2) there are teachers who lack enthusiasm in carrying out their tasks, such as returning to work before their time and entering if there are only teaching assignments, (3) there are still teachers who have low desire to carry out their tasks, such as the presence of teachers who come late to school; (4) the low responsibility of teachers in carrying out tasks, where there are teachers who are unable to complete the tasks assigned to them properly such as not picket. Therefore, there is a need to increase teaching motivation, organizational culture and professional competence, and the level of teacher education so that progress toward optimal teacher performance can be realized. 


\section{Conclusion}

Based on the results of research that has been done related to the influence of motivation, organizational culture and performance on the professionalism of teachers in MTs Tayu, it can be concluded several things:

1. Motivation has a positive and significant effect on teacher performance in MTs Tayu

2. Organizational Culture has a positive and significant effect on teacher performance in MTs Tayu.

3. Performance has a positive and significant effect on teacher professionalism at MTs Tayu.

4. Motivation, organizational culture and performance have a positive and significant effect simultaneously on teacher professionalism at MTs Tayu.

\section{References}

[1] Brown D.R dan harvey, D. 2006. An Experimental Approach to Organization Development. New jersey: Pearson Education

[2] Ferdinan, Augusty. 2013. Metode Penelitian Manajemen. Edisi 5. Badan Penerbit, Universitas Diponegoro : Semarang

[3] Funmimola, Oyebamiji Florence, Kareem Thompson Sola, Ayeni Gabriel Olusola. 2013. Impact of Job Satisfaction Dimensions on Job performance in a small and medium Enterpise in Ibadan, South Western, Nigeria. Interdisiplinary Journal of Contemporary Research in Business. Vol 4, No 11.pp.509-521

[4] Hasibuan, M.S.P. 2009. Manajemen: Dasar, Pengertian dan Makalah. (Edisi Revisi). Jakarta: Bumi Aksara

[5] Kunandar. 2007. Guru Profesional. Jakarta: P Raja Grafindo Persada

[6] Latif, Zulkrfi MA., Ridwan,. Dan C. Totanan. 2017. Pengaruh Kompetensi Profesional dan Pedagogik terhadap Kinerja Guru Akutansi pada Madrasah Aliyah Negeri di Kota Palu. e Journal Katalogis, Volume 5 Nomor 3, Maret 2017 hlm 67-77.

[7] Luthans, F. 2006. Perilaku Organisasi. Edisi sepuluh. Ypgyakarta: ANDI

[8] Mangkunegara, Anwar Prabu. 2011. Manajemen Sumber daya Manusia Perusahaan. Bandung: Remaja Rosdakarya

[9] Mulyasa. E (2012). Manajemen dan Kepemimpinan Kepala Sekolah. Jakarta: PT Bumi Aksara

[10] Oxy Rindiantika Sari dan Heru Susilo. 2018. Pengaruh kepuasan kerja terhadap kinerja karyawan dengan organizational citizenship behavior sebagai variabel intervening (studi pada karyawan ptpn $\mathrm{x}$ - unit usaha pabrik gula modjopanggoong tulungagung). Jurnal Administrasi Bisnis (JAB),Vol. 64 No. 1 November 2018 hal 28-35.

[11] Peraturan Pemerintah Republik Indonesia Nomor 74 tahun 2008 tentang Guru

[12] Peraturan Pemerintah Republik Indonesia Nomor 19 tahun 2005 tentang Standar Nasional Pendidikan. 2005. Jakarta: CV. Eko Jaya

[13] Robbins, S.P. dan Judge, T.A. 2012. Perilaku Organisasi (Organizational Behavior). Buku 1. Edisi kedua belas. Alih bahasa: Diana Angelica, Ria cahyani, dan Abdul Rosyid. Jakarta: Salemba Empat

[14] Radar Lampung, Harian. Kamis - 22 November 2012. Menjadi Guru di Era Perubahan. http://dwi-rohmadi.blogspot.com/2012/12/menjadi-guru-di-era-perubahanhtml-12-18-2013jam11.33 
[14] Saleem, Rizwar, Azeem Mahmood, Asif mahmood. Effect of Work Motivation on Job satisfaction in Mobile Telecomunication Service Organizations of Pakistan. International journal of Business and management. Vol. 5, No. 11. Pp.213-222

[15] Supardi. Kinerja Guru. Jakarta: rajawali Press, 2013

[16] Schunk, D. H., Pintrich, P.R., \& Meece, J. R. 2010. Motivation in Education" Theory, Research, and Applications. Upper Saddle river, New Jersey : Pearson Education

[17] Sugiyono. 2016. Metode Penelitian Kuantitatif Kualitatif dan R\&D. Alfabeta : Bandung.Undang-undang Nomor 14 tahun 2005 tentang Guru dan Dosen

[18] Uno, Hamzah B. 2011. Teori Motivasi dan Pengukurannya. Jakarta : Bumi Aksara 